\title{
Hubungan persepsi masyarakat pesisir tentang KKLD dan partisipasi masyarakat pesisir terhadap pengelolaan KKLD Lampung Barat
}

\author{
A. Suryanda ${ }^{1 *}$, R. Komala ${ }^{2}$, R. Fahlevi ${ }^{1}$ \\ ${ }_{1}^{1}$ Program Studi Pendidikan Biologi, Universitas Negeri Jakarta, Jakarta, Indonesia \\ ${ }^{2}$ Program Studi Biologi, Universitas Negeri Jakarta, Jakarta, Indonesia
}

\begin{abstract}
Abstrak.
Ekosistem pesisir dan laut merupakan ekosistem yang sangat produktif. Secara sosial ekonomi, masyarakat pesisir sangat bergantung pada pemanfaatan sumber daya yang ada di wilayahnya. Peningkatan aktivitas masyarakat pesisir dapat mempengaruhi kelangsungan dan keseimbangan pemenuhan kebutuhan sumber daya di masa mendatang. Penelitian ini bertujuan mengetahui hubungan persepsi masyarakat pesisir tentang Kawasan Konservasi Laut Daerah (KKLD) dan partisipasi masyarakat pesisir dengan pengelolaan KKLD Lampung Barat. Sampel penelitian ini sebanyak 248 responden. Pengambilan sampel menggunakan teknik convenience sampling. Pengumpulan data dilakukan dengan menggunakan kuesioner persepsi dan partisipasi kemudian dianalisis menggunakan uji prasyarat. Hasil pengujian prasyarat menunjukkan data terdistribusi normal dan homogen dengan persamaan regresi $\hat{Y}=28,478+0,667 X$. Perhitungan koefisien korelasi menunjukkan nilai $r x y=0,582$, artinya kekuatan hubungan antara variabel $\mathrm{x}$ dan $\mathrm{y}$ tergolong kategori sedang. Terdapat hubungan positif antara persepsi masyarakat pesisir tentang KKLD dan partisipasi masyarakat pesisir terhadap pengelolaan KKLD Lampung Barat.
\end{abstract}

Kata kunci: KKLD, masyarakat pesisir, persepsi, partisipasi

\begin{abstract}
.
Coastal and marine ecosystems are productive ecosystems. Socioeconomically, coastal communities rely heavily on the utilization of existing resources in their region. Increased coastal community activity may affect the viability and balance of future resource requirements. This research aimed to determine the relation of coastal community perception about Marine Management Area (MMA) and coastal community participation with management of West Lampung MMA. The sample of this research were 248 respondents. Sampling used convenience sampling technique. Data collection was done by using perception questionnaire and participation then analysed by prerequisite test. Prerequisite test results showed normal and homogeneous distributed data with regression equation of $\hat{Y}=28,478+0,667 X$. Calculation of correlation coefficient showed the value of rxy $=0.582$, it means that the strength of the relationship between variables $x$ and $y$ was categorized as intermediate. There was a positive correlation between the perception of coastal community about MMA and the participation of coastal communities with management of West Lampung MMA.
\end{abstract}

Keywords: MMA, coastal community, perception, participation

\section{PENDAHULUAN}

Kabupaten Pesisir Barat merupakan kabupaten termuda yang ada di Provinsi Lampung Barat. Kabupaten ini dibentuk berdasarkan UU Nomor 22 Tahun 2012 tentang Pembentukan Kabupaten Pesisir Barat di Provinsi Lampung. Kabupaten Pesisir Barat memiliki luas wilayah $\pm 2.889,88 \mathrm{~km}^{2}$ dengan panjang pesisir $\pm 210 \mathrm{~km}$. Berhadapan dengan Samudera Hindia dan dikelilingi hutan tropis Taman Nasional Bukit Barisan Selatan, kabupaten ini mempunyai potensi yang luar biasa dalam pemanfaatan ekosistem pesisir dan laut (Diskominfo Kabupaten Pesisir Barat 2020). Berdasarkan data BPS Kabupaten Lampung Barat (2018), produksi hasil perikanan Kabupaten Pesisir Barat pada tahun 2016 sebesar 16.569,85 ton. Namun, potensi tersebut dapat menurun

\footnotetext{
${ }^{*}$ Korespondensi Penulis

Email : asuryanda@unj.ac.id
} 
seiring dengan meningkatnya aktivitas masyarakat dalam memanfaatkan sumber daya yang tersedia. Aktivitas yang dilakukan masyarakat tidak selalu berdampak positif, adakalanya aktivitas tersebut menimbulkan dampak negatif bagi ekosistem. Peningkatan aktivitas masyarakat pesisir seperti penambakan udang dan penambangan pasir laut dapat mempengaruhi kelangsungan dan keseimbangan pemenuhan kebutuhan sumber daya pada masa mendatang.

Bertujuan dalam menjaga kelestarian ekosistem pesisir dan laut yang dimiliki oleh Kabupaten Pesisir Barat, Pemerintah Kabupaten Lampung Barat (sebelum pemekaran) dan Dinas Kelautan dan Perikanan Provinsi Lampung menetapkan Kawasan Konservasi Laut Daerah (KKLD) Lampung Barat. Pendirian dan penetapan KKLD Lampung Barat ini merupakan upaya preventif untuk melindungi sumber daya laut dan pesisir yang dimiliki. Pendirian KKLD Lampung Barat mempunyai harapan agar masyarakat pesisir dapat berpartisipasi dalam menjaga sumber daya yang ada. Tetapi, berdasarkan hasil evaluasi efektivitas pengelolaan kawasan konservasi perairan, pesisir dan pulaupulau kecil menunjukkan bahwa pengelolaan KKLD Lampung Barat tetap berjalan lambat (KepDirJen KP3K 2012).

Persepsi dapat mempengaruhi tingkat partisipasi masyarakat. Partisipasi masyarakat pesisir yang rendah dapat disebabkan oleh kurangnya informasi atau adanya kekeliruan informasi mengenai KKLD. Salah satu faktor lambatnya pengelolaan KKLD di Lampung Barat juga dapat disebabkan oleh hal tersebut. Menurut Baba et al. (2011), persepsi yang rendah terhadap suatu objek menghasilkan tingkat partisipasi yang rendah pula. Hal tersebut membuktikan bahwa tinggi atau rendahnya persepsi tentang kawasan konservasi akan berpengaruh pada tingkat partisipasi yang akan diberikan masyarakat dalam pengelolaan kawasan konservasi. Adhian et al. (2014) memperkuat hal tersebut, bahwa masyarakat yang mempunyai persepsi benar akan berpartisipasi positif terhadap upaya-upaya konservasi. Jika persepsi yang dimiliki masyarakat pesisir tentang KKLD itu baik, maka akan mampu menghasilkan partisipasi yang besar untuk menjaga keberlangsungan KKLD. Berdasarkan permasalahan tersebut, penelitian ditujukan untuk menguraikan hubungan persepsi masyarakat pesisir tentang KKLD dengan partisipasi masyarakat pesisir terhadap pengelolaan KKLD Lampung Barat.

\section{METODOLOGI}

\subsection{Lokasi kajian dan waktu penelitian}

Penelitian ini dilakukan pada tahun 2019 di tiga desa yang masuk dalam Kecamatan Ngambur yaitu Desa Muara Tembulih, Sukanegara dan Gedung Cahya Kuningan. Dasar penentuan ketiga lokasi tersebut adalah karena termasuk dalam area KKLD Lampung Barat. 


\subsection{Metode pengambilan sampel}

Populasi target yang digunakan adalah seluruh masyarakat pesisir di Kabupaten Pesisir Barat. Populasi terjangkau adalah masyarakat pesisir di Kecamatan Ngambur. Penentuan kecamatan ditentukan melalui purposive sampling dengan pertimbangan bahwa kecamatan ini memiliki desa yang berdekatan dengan KKLD.

Jumlah sampel sebanyak 248 orang dengan rentang usia 17-60 tahun dari ketiga desa yang masuk dalam wilayah KKLD Lampung Barat. Penentuan jumlah responden menggunakan rumus Taro Yamane, sedangkan penentuan rentang usia ditentukan melalui convenience sampling. Convenience sampling adalah pengambilan sampel yang didasarkan pada ketersediaan elemen dan kemudahan untuk mendapatkannya. Responden yang dijadikan sampel merupakan responden yang pada saat pengambilan sampel berada pada lokasi pengambilan.

Pengukuran tingkat persepsi dan partisipasi masyarakat pesisir digali menggunakan kuesioner dengan Skala Likert yang terdiri dari empat kategori penilaian yaitu sangat setuju, setuju, tidak setuju dan sangat tidak setuju. Selanjutnya skor persepsi dan partisipasi diubah menjadi nilai melalui Rumus 1.

\subsection{Prosedur analisis data}

Metode analisis data yang digunakan yaitu metode deskriptif dan kualitatif. Metode kualitatif yang dimaksud adalah analisis regresi sederhana dengan variabel bebas $(\mathrm{X})$ yaitu persepsi masyarakat pesisir tentang KKLD dan variabel terikat (Y) yaitu partisipasi masyarakat pesisir terhadap pengelolaan KKLD Lampung Barat. Tahapan yang dilakukan dijelaskan sebagai berikut.

1. Uji Prasyarat

a. Uji normalitas, untuk mengetahui apakah sebaran data normal atau tidak dengan menggunakan uji Kolmogorov Smirnov pada tingkat signifikansi $\alpha$ $=0,05$.

b. Uji homogenitas, untuk mengetahui apakah sebaran data homogen atau tidak dengan menggunakan uji Levene dengan aplikasi SPSS 19.

2. Uji Hipotesis

a. Uji regresi linier sederhana, untuk menguji atau memprediksi pengaruh variabel bebas $(\mathrm{X})$ terhadap variabel terikat $(\mathrm{Y})$. Persamaan regresi dirumuskan: $\hat{Y}=a+b X$.

b. Uji keberartian model regresi, kriteria pengujian jika nilai signifikansi data $<\alpha(0,05)$, maka model regresi $\hat{Y}=a+b X$ signifikan. 
c. Uji linieritas, kriteria pengujian jika nilai signifikansi data $<\alpha(0,05)$, maka model regresi $\hat{Y}=a+b X$ mempunyai hubungan yang linier.

d. Uji keberartian koefisien korelasi, untuk membandingkan hasil pengukuran dua variabel yang berbeda agar dapat menentukan tingkat hubungan antara variabel. Uji korelasi menggunakan rumus Pearson Product Moment. Kriteria pengujian, jika nilai signifikansi data $<\alpha(0,05)$, maka koefisien korelasi signifikan dan terdapat hubungan antar kedua variabel.

e. Penentuan koefisien determinasi $\left(\mathrm{r}_{\mathrm{xy}}{ }^{2} \mathrm{x}\right.$ 100\%), untuk mengetahui besarnya kontribusi variabel $X$ (Persepsi masyarakat pesisir tentang KKLD) terhadap variabel Y (Partisipasi masyarakat pesisir terhadap pengelolaan KKLD Lampung Barat).

\section{HASIL DAN PEMBAHASAN}

\subsection{Karakteristik responden}

Observasi tentang kehidupan sosial responden dilakukan terhadap 248 orang. Berdasarkan observasi, diperoleh hasil karakteristik responden yaitu jenis kelamin, tingkat pendidikan dan mata pencaharian. Karakteristik responden selengkapnya dapat dilihat pada Tabel 1.

Tabel 1. Karakteristik responden ketiga desa.

\begin{tabular}{|c|c|c|c|c|c|c|}
\hline \multirow[b]{2}{*}{ No } & \multirow[b]{2}{*}{ Identitas } & \multirow[b]{2}{*}{ Komponen } & \multicolumn{3}{|c|}{ Desa } & \multirow[b]{2}{*}{ Total } \\
\hline & & & $\begin{array}{c}\text { Muara } \\
\text { Tumbulih }\end{array}$ & Sukanegara & $\begin{array}{c}\text { Gd. Cahya } \\
\text { Kuning }\end{array}$ & \\
\hline \multirow{3}{*}{1} & Jenis & Laki-laki & 57 & 49 & 64 & 170 \\
\hline & Kelamin & Perempuan & 25 & 29 & 24 & 78 \\
\hline & Total & & 82 & 78 & 88 & 248 \\
\hline \multirow{6}{*}{2} & \multirow{5}{*}{ Pendidikan } & Tidak Bersekolah & 28 & 32 & 26 & 86 \\
\hline & & SD & 33 & 19 & 39 & 91 \\
\hline & & SMP & 12 & 17 & 14 & 43 \\
\hline & & SMA & 8 & 10 & 6 & 24 \\
\hline & & DIII/S1 & 1 & 0 & 3 & 4 \\
\hline & Total & & 82 & 78 & 88 & 248 \\
\hline \multirow{7}{*}{3} & \multirow{6}{*}{$\begin{array}{l}\text { Mata } \\
\text { Pencaharian }\end{array}$} & Petani & 60 & 53 & 61 & 174 \\
\hline & & Peternak & 2 & 1 & 0 & 3 \\
\hline & & Pedagang & 4 & 5 & 8 & 17 \\
\hline & & Pegawai Pemerintah & 4 & 4 & 9 & 17 \\
\hline & & Jasa & 3 & 4 & 7 & 14 \\
\hline & & Tidak Bekerja & 9 & 11 & 3 & 23 \\
\hline & Total & & 82 & 78 & 88 & 248 \\
\hline
\end{tabular}

Secara umum, responden berjenis kelamin laki-laki lebih dominan dibandingkan dengan responden berjenis kelamin perempuan. Berdasarkan hasil wawancara, mayoritas responden hanya mampu mengenyam pendidikan 
sampai tingkat SD dengan total 91 orang $(36,67 \%)$ dan total responden yang mengenyam pendidikan hingga tingkat perguruan tinggi hanya sebanyak 4 orang $(1,61 \%)$. Karakteristik responden terakhir yaitu mata pencaharian yang mayoritas merupakan petani dengan total 174 responden $(70,16 \%)$ dan yang sedikit adalah peternak dengan total 3 responden $(1,20 \%)$.

\subsection{Persepsi masyarakat pesisir tentang KKLD}

Persepsi masyarakat pesisir tentang KKLD digali menggunakan kuesioner dengan Skala Likert yang terdiri dari empat kategori yaitu Sangat Tidak Setuju (STS), Tidak Setuju (TS), Setuju (S) dan Sangat Setuju (SS). Pernyataan positif SS bernilai 4 , S bernilai 3, TS bernilai 2 , STS bernilai 1, sedangkan untuk pernyataan negatif STS bernilai 4, TS bernilai 3, S bernilai 2 dan SS bernilai 1. Dimensi dan indikator persepsi masyarakat pesisir tentang KKLD dijelaskan pada Tabel 2.

Tabel 2. Persepsi masyarakat pesisir tentang KKLD.

\begin{tabular}{llc}
\hline Dimensi persepsi & Indikator & $\begin{array}{c}\text { Jumlah } \\
\text { pertanyaan }\end{array}$ \\
\hline Pengetahuan tentang & Latar belakang KKLD & 5 \\
KKLD & Keberadaan KKLD & 5 \\
\hline \multirow{2}{*}{ Status Sosial Ekonomi } & Pengaruh KKLD terhadap sosial & 4 \\
& Pengaruh KKLD pada kehidupan ekonomi & 4 \\
\hline \multirow{2}{*}{ Kondisi Biofisik KKLD } & Kondisi terumbu karang & 4 \\
& Aktivitas pariwisata & 2 \\
& Keberadaan Penyu & 6 \\
\hline Ancaman dan & Persepsi ancaman di KKLD & 3 \\
Permasalahan & Persepsi permasalahan di KKLD & 2 \\
\hline \multirow{2}{*}{ Peraturan } & Persepsi peraturan di batas zonasi dan pengaruhnya & 4 \\
\hline \multirow{2}{*}{ Kepedulian } & Sosialisasi peraturan di KKLD & 4 \\
\hline Keterlibatan dan & Pengamatan pelanggaran oleh masyarakat pesisir & 3 \\
Kepuasan & Pengamatan pelanggaran oleh pariwisata & 7 \\
\hline
\end{tabular}

\subsubsection{Berdasarkan jenis kelamin responden}

Hasil penelitian memperlihatkan bahwa persepsi masyarakat pesisir tentang KKLD tidak dipengaruhi oleh jenis kelamin. Skor persepsi masyarakat pesisir tentang KKLD yang berjenis kelamin laki-laki ataupun perempuan mempunyai skor rata-rata yang sama yaitu sebesar 75,4 (Gambar 1). Hasil penelitian ini berbeda dengan Muchlas (2005) yang menyatakan bahwa jenis kelamin merupakan salah satu faktor yang dapat mempengaruhi persepsi masyarakat. Hal ini diduga bisa disebabkan masyarakat Lampung Barat memiliki kesadaran kesetaraan gender dalam berperan serta dan dapat melakukan pembagian peran di antara mereka. 


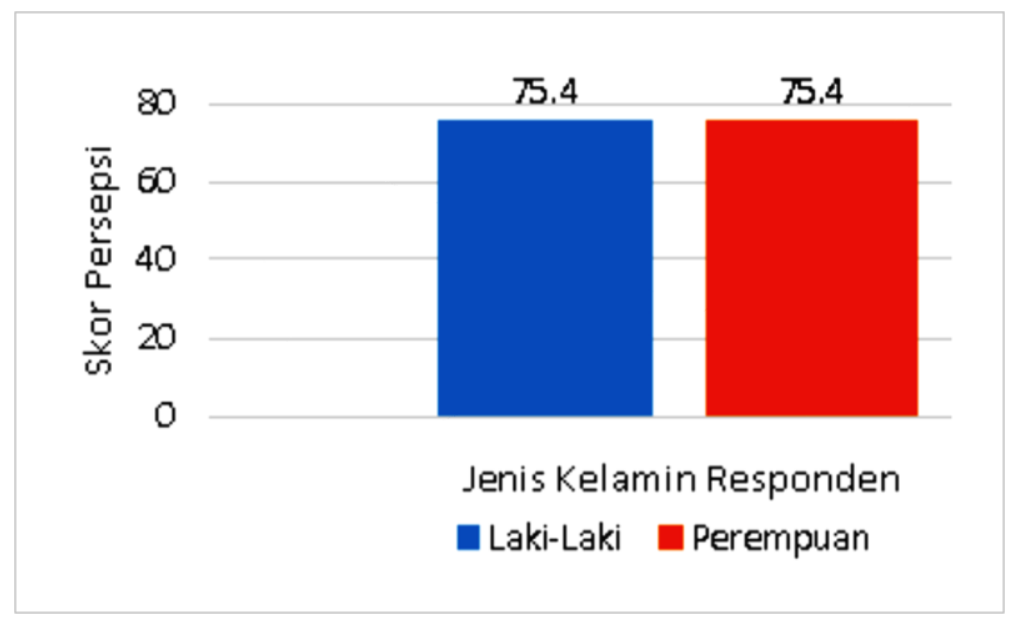

Gambar 1. Rata-rata skor persepsi tentang KKLD berdasarkan jenis kelamin.

\subsubsection{Berdasarkan tingkat pendidikan responden}

Hasil persepsi masyarakat pesisir tentang KKLD tertinggi berada pada kelompok responden berpendidikan tinggi yakni dengan skor 85 (Gambar 2). Hal tersebut sesuai dugaan sebelumnya yaitu tingkat pendidikan responden dapat mempengaruhi persepsi masyarakat pesisir tentang KKLD. Tingginya pendidikan yang diperoleh akan membuat peluang pengetahuan dan kesadaran terhadap KKLD menjadi lebih baik. Hasil temuan ini diperkuat oleh Mamuko et al. (2016) yang menyatakan bahwa tingkat pendidikan dapat mempengaruhi persepsi dan partisipasi masyarakat. Menurutnya, tingkat pendidikan responden sangat berpengaruh dalam pembentukan pola pikir terhadap segala perubahan yang terjadi di lingkungan sekitarnya, termasuk kegiatan pengelolaan KKLD Lampung Barat.

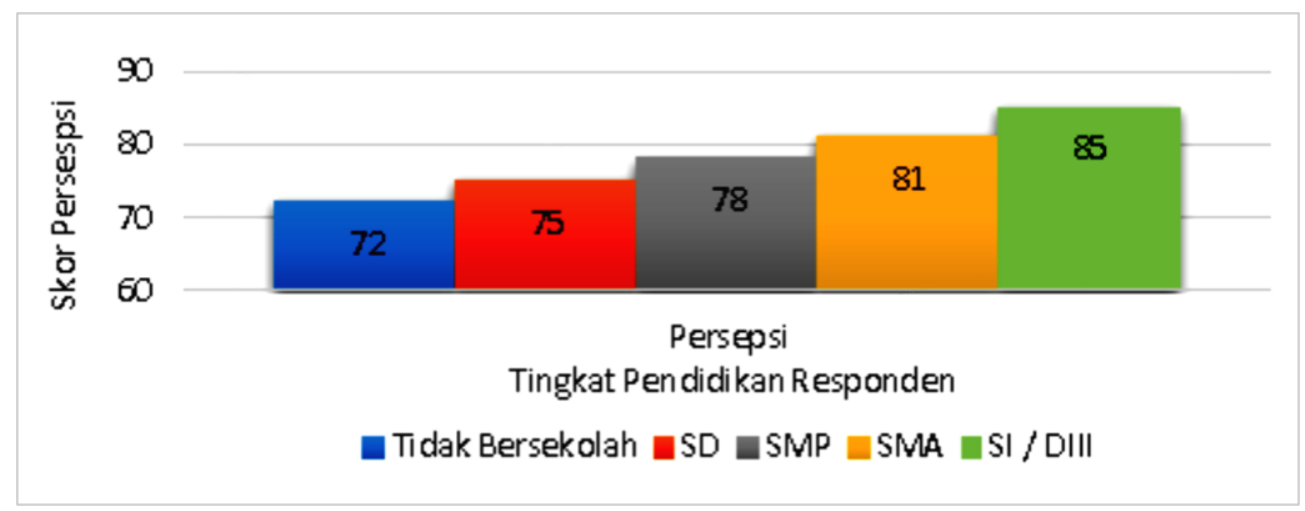

Gambar 2. Rata-rata skor persepsi berdasarkan tingkat pendidikan. 


\subsubsection{Berdasarkan mata pencaharian responden}

Persepsi masyarakat pesisir tentang KKLD tertinggi berada pada kelompok masyarakat yang mempunyai mata pencaharian sebagai peternak dan pegawai pemerintahan dengan skor 82 (Gambar 3). Hasil penelitian memperlihatkan bahwa mata pencaharian mempengaruhi persepsi seseorang. Tingginya skor pada responden dengan mata pencaharian pegawai pemerintahan diduga karena adanya tanggung jawab moril untuk menjadi contoh positif bagi masyarakat di sekitarnya. Skor tertinggi pada responden dengan mata pencaharian peternak disebabkan oleh interaksi dan manfaat yang dirasakan dari KKLD, sehingga persepsi terhadap KKLD menjadi baik. Kozier (2004) dalam Nurhidayat (2012) juga menyatakan bahwa status pekerjaan atau mata pencaharian sangat mempengaruhi persepsi seseorang.

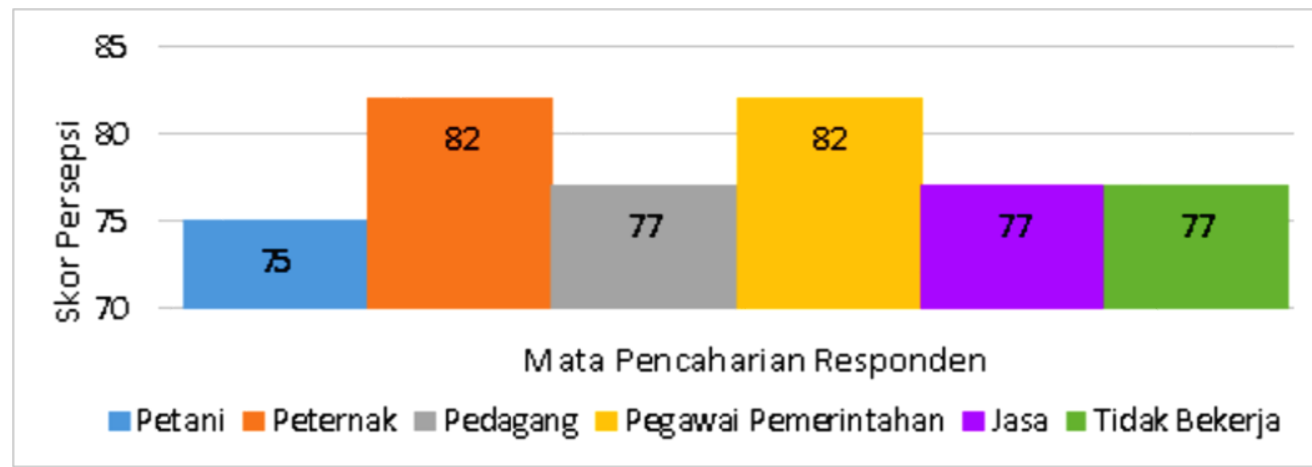

Gambar 3. Rata-rata skor persepsi berdasarkan mata pencaharian.

\subsection{Partisipasi masyarakat pesisir terhadap pengelolaan KKLD Lampung Barat}

Partisipasi masyarakat yang diukur berupa bentuk dan proses partisipasi. Kedua dimensi ini memiliki beberapa indikator yang kemudian dibuat pertanyaan-pertanyaan untuk menggali partisipasi tersebut. Dimensi dan indikator partisipasi masyarakat pesisir terhadap pengelolaan KKLD dapat dilihat pada Tabel 3.

Tabel 3. Partisipasi masyarakat pesisir tentang KKLD.

\begin{tabular}{llc}
\hline Dimensi partisipasi & Indikator & Jumlah pertanyaan \\
\hline \multirow{4}{*}{ Bentuk Partisipasi } & Kontribusi Pemikiran & 5 \\
& Kontribusi Dana/Finansial & 5 \\
& Kontribusi Tenaga & 9 \\
& Kontribusi Sarana & 3 \\
\hline \multirow{3}{*}{ Proses Partisipasi } & Partisipasi dalam Perencanaan & 5 \\
& Partisipasi dalam Pelaksanaan & 5 \\
& Partisipasi dalam evaluasi & 7 \\
\hline
\end{tabular}




\subsubsection{Berdasarkan jenis kelamin responden}

Partisipasi masyarakat pesisir terhadap KKLD Lampung Barat berjenis kelamin laki-laki mempunyai skor sebesar 78,9, sedangkan yang berjenis kelamin perempuan mempunyai skor sebesar 78,6. Berdasarkan Gambar 4, didapatkan hasil bahwa jenis kelamin dapat mempengaruhi partisipasi masyarakat pesisir terhadap pengelolaan KKLD Lampung Barat. Hasil ini sesuai dengan dugaan sebelumnya yang menyatakan bahwa jenis kelamin dapat mempengaruhi tingkat partisipasi. Partisipasi yang terlihat adalah berusaha melaporkan jika ada masyarakat atau wisatawan yang tertangkap merusak fasilitas KKLD kepada pengelola, terlibat dalam rapat-rapat penentuan program atau implementasi kegiatan KKLD dan terlibat dalam kegiatan transplantasi karang maupun penanaman mangrove.

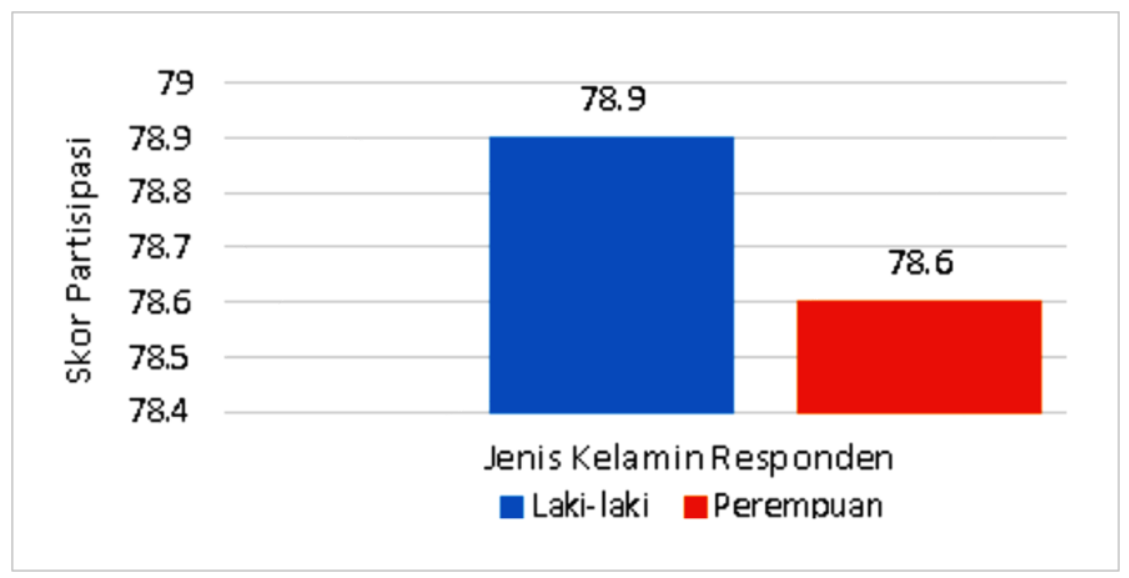

Gambar 4. Rata-rata partisipasi berdasarkan jenis kelamin.

Soedarno et al. (1992) dalam Sutami (2009) menyatakan bahwa golongan pria mempunyai hak istimewa dibandingkan dengan golongan perempuan. Dengan demikian, kelompok pria akan lebih banyak berpartisipasi dalam pengelolaan KKLD. Hal tersebut juga diperkuat oleh Mubarak (2010) yang menyatakan bahwa kaum laki-laki memberikan respon yang lebih baik terhadap program pengelolaan dan pemberdayaan kawasan dibandingkan dengan kaum perempuan. Kendala partisipasi pada perempuan yaitu berupa waktu, dana dan pengetahuan dari perempuan itu sendiri mengenai partisipasi dalam pengelolaan KKLD (Monica dan Fauziah 2017).

\subsubsection{Berdasarkan tingkat pendidikan responden}

Masyarakat pesisir dengan tingkat pendidikan SMA dan perguruan tinggi menunjukkan skor partisipasi tertinggi dengan skor 84 (Gambar 5). Berdasarkan hasil penelitian ini, diketahui bahwa tingkat pendidikan mempengaruhi partisipasi masyarakat pesisir terhadap pengelolaan KKLD 
Lampung Barat. Hal ini sesuai dugaan sebelumnya yakni tingginya tingkat pendidikan akan memberikan dampak positif terhadap partisipasi masyarakat pesisir dalam pengelolaan KKLD Lampung Barat. Tingginya tingkat pendidikan seseorang memudahkan orang tersebut menyerap informasi dan hasil dari sebuah diskusi, serta pada saat melakukan implementasi dari sebuah kebijakan, sehingga pada akhirnya persepsi yang terbentuk akan menjadi lebih baik. Baba et al. (2011) dan Haryanto dan Sriyono (2015) juga menyatakan bahwa persepsi yang tinggi terhadap suatu objek mampu menghasilkan tingkat partisipasi yang tinggi pula. Gambar 5 menunjukkan bahwa skor partisipasi semakin meningkat seiring dengan meningkatnya tingkat pendidikan yang dimiliki oleh responden.

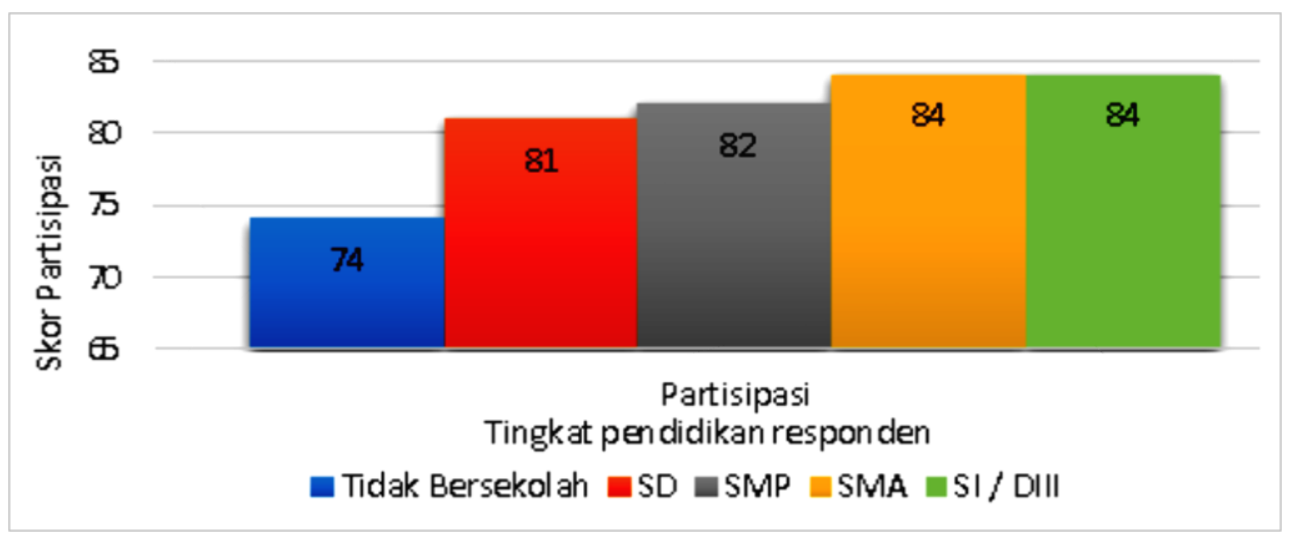

Gambar 5. Rata-rata skor partisipasi berdasarkan tingkat pendidikan.

\subsubsection{Berdasarkan mata pencaharian responden}

Partisipasi masyarakat pesisir terhadap pengelolaan KKLD Lampung Barat tertinggi berada pada kelompok responden yang mempunyai mata pencaharian sebagai pegawai pemerintahan dengan skor 84 (Gambar 6). Hasil ini disebabkan karena seseorang yang mempunyai posisi penting dalam mata pencaharian di lingkungannya akan memberikan contoh partisipasi yang baik dalam pengelolaan KKLD. Contoh partisipasi yang baik dalam pengelolaan KKLD akan mempengaruhi partisipasi masyarakat yang ada di sekelilingnya.

Fatah (2006) dalam Nur et al. (2011) menyampaikan bahwa partisipasi sangat erat kaitannya dengan tingkat penghasilan atau tingkat kesejahteraan. Mata pencaharian yang sedikit lebih maju dan tingkat penghasilan yang lebih tinggi akan mempengaruhi tingkat partisipasi, karena mata pencaharian berpengaruh terhadap waktu luang yang dimiliki untuk terlibat dalam pengelolaan KKLD. Masyarakat dengan tingkat kesejahteraan yang baik akan mempunyai waktu dan kesempatan berpartisipasi yang baik pula, sementara masyarakat dengan tingkat kesejahteraan kurang baik lebih menggunakan waktu luang mereka untuk mencari nafkah. Nur et al. (2011) menambahkan 
bahwa tingkat kesejahteraan akan mempengaruhi secara langsung kemampuan kontribusi masyarakat baik berupa dana, materiil maupun tenaga. Masyarakat pesisir dapat berpartisipasi apabila kebutuhan dasarnya sudah tercukupi.

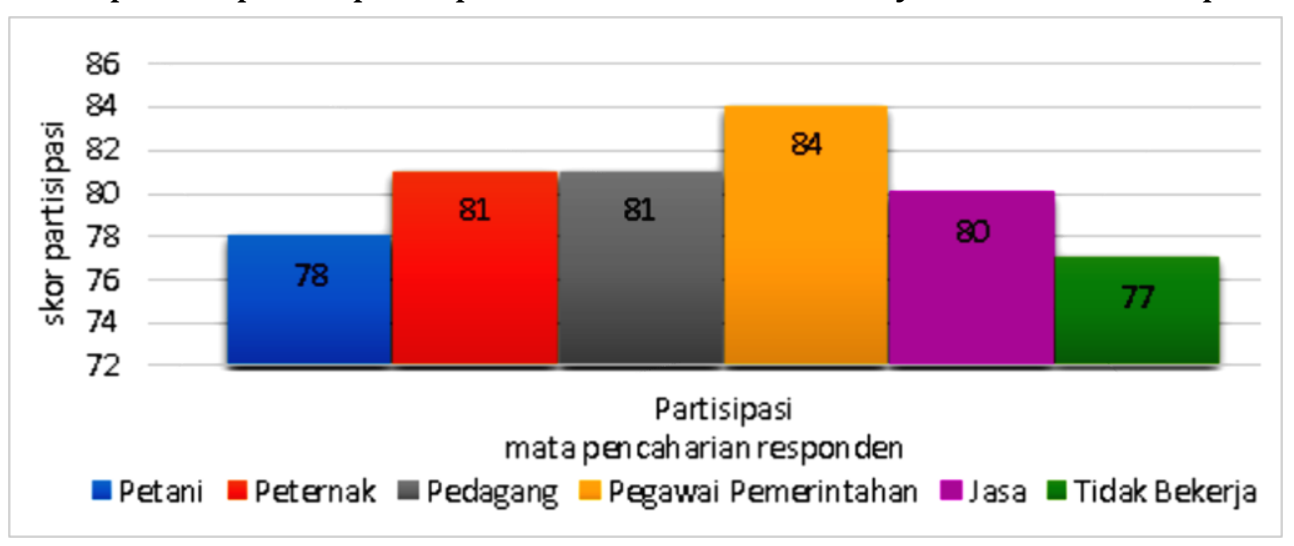

Gambar 6. Rata-rata skor partisipasi berdasarkan mata pencaharian.

\subsection{Hubungan persepsi dan partisipasi masyarakat pesisir}

\subsubsection{Frekuensi nilai persepsi masyarakat pesisir tentang KKLD}

Berdasarkan hasil penelitian, nilai tertinggi persepsi masyarakat pesisir tentang KKLD adalah 87 dan nilai terendah adalah 59. Nilai rata-rata persepsi masyarakat pesisir tentang KKLD adalah 75,4. Frekuensi skor persepsi masyarakat pesisir tentang KKLD paling banyak terdapat pada rentang nilai 7476 sebanyak 84 responden $(33,90 \%)$ dan yang paling sedikit berada pada rentang nilai 59-61 sebanyak 1 responden $(0,4 \%)$. Data tersebut memberikan gambaran bahwa persepsi masyarakat Desa Muara Tembulih, Sukanegara dan Gedung Cahya Kuningan, Kecamatan Ngambur tergolong tinggi berdasarkan kriteria Arikunto (2008). Histogram distribusi frekuensi nilai persepsi masyarakat pesisir tentang KKLD dapat dilihat pada Gambar 7.

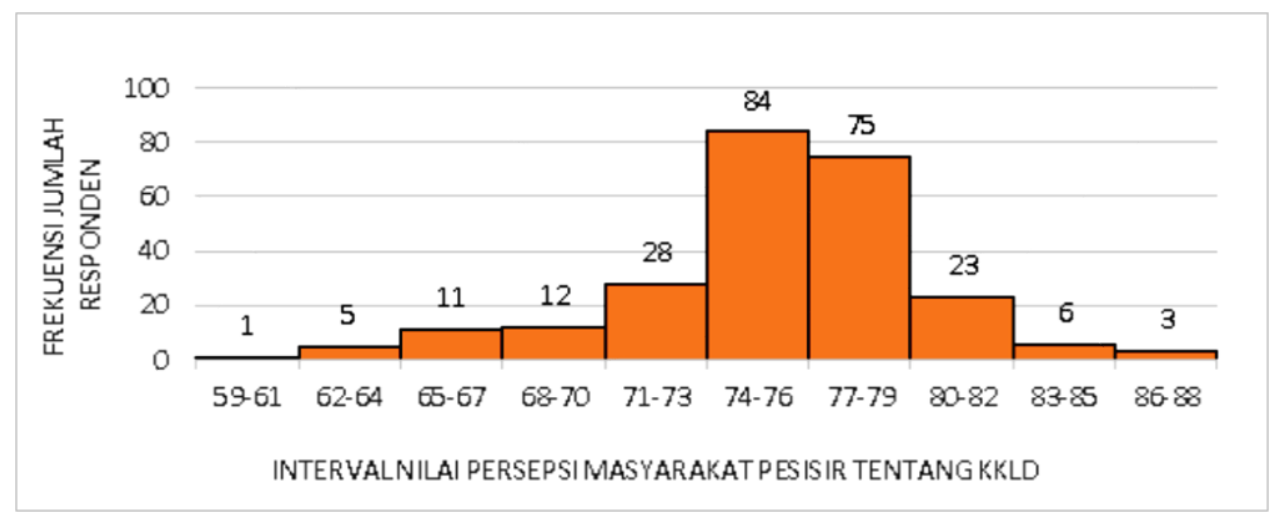

Gambar 7. Histogram distribusi frekuensi nilai persepsi masyarakat pesisir tentang KKLD. 


\subsubsection{Frekuensi nilai partisipasi masyarakat pesisir terhadap pengelolaan KKLD Lampung Barat}

Frekuensi skor partisipasi masyarakat pesisir terhadap pengelolaan KKLD Lampung Barat paling banyak terdapat pada rentang nilai 80-82 sebanyak 59 responden $(23,80 \%)$ dan yang paling sedikit berada pada rentang nilai $62-64$ sebanyak 1 responden $(0,4 \%)$. Nilai tertinggi partisipasi masyarakat pesisir terhadap pengelolaan KKLD Lampung Barat adalah 91, sedangkan nilai terendah adalah 62. Nilai rata-rata partisipasi masyarakat pesisir terhadap pengelolaan KKLD Lampung Barat adalah 78,8. Data tersebut memberikan gambaran bahwa partisipasi masyarakat Desa Muara Tembulih, Sukanegara dan Gedung Cahya Kuningan, Kecamatan Ngambur tergolong tinggi berdasarkan kriteria Arikunto (2008). Histogram frekuensi nilai partisipasi masyarakat pesisir terhadap pengelolaan KKLD Lampung Barat dapat dilihat pada Gambar 8.

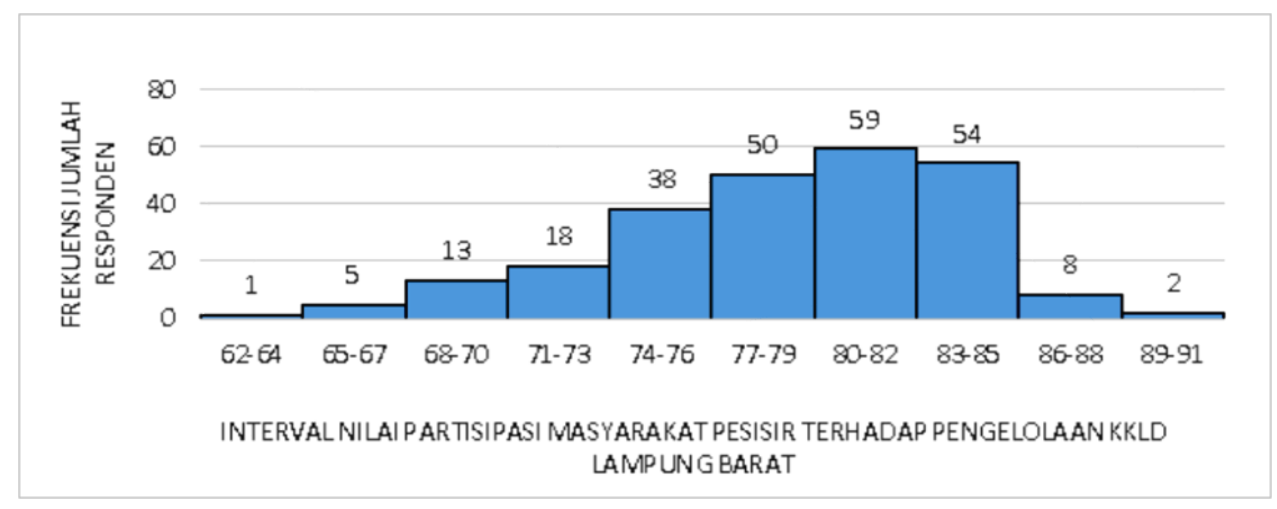

Gambar 8. Histogram distribusi frekuensi nilai partisipasi masyarakat pesisir terhadap pengelolaan KKLD Lampung Barat.

\subsubsection{Korelasi antara persepsi dan partisipasi masyarakat pesisir terhadap KKLD Lampung Barat}

Berdasarkan analisis data hasil penelitian, diperoleh persamaan regresi $\hat{Y}=28,478+0,667 \mathrm{X}$ yang menunjukkan adanya hubungan positif antara persepsi masyarakat pesisir tentang KKLD dengan partisipasi masyarakat pesisir terhadap pengelolaan KKLD Lampung Barat (Gambar 9). Kekuatan hubungan antara dua variabel termasuk dalam kategori sedang dengan nilai koefisien korelasi sebesar 0,582. Hal tersebut dapat diartikan bahwa peningkatan persepsi masyarakat pesisir tentang KKLD diikuti dengan meningkatnya partisipasi masyarakat pesisir terhadap pengelolaan KKLD Lampung Barat. Semakin baiknya persepsi masyarakat pesisir tentang KKLD dapat dijadikan modal awal untuk meningkatkan partisipasi masyarakat pesisir terhadap pengelolaan KKLD. 


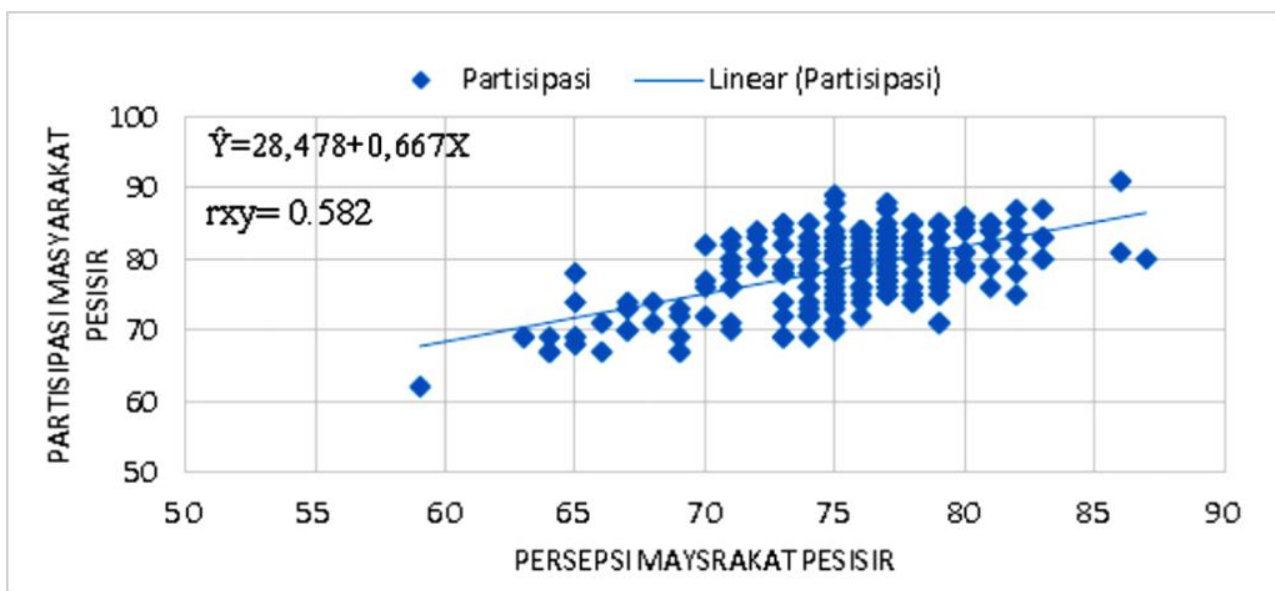

Gambar 9. Diagram scatter hubungan linieritas persepsi masyarakat pesisir tentang KKLD dengan partisipasi masyarakat terhadap pengelolaan KKLD Lampung Barat.

Terlihat pada Gambar 9 bahwa kedua variabel searah, artinya apabila persepsi masyarakat pesisir tentang KKLD semakin baik, maka partisipasi masyarakat pesisir dalam pengelolaan KKLD Lampung Barat akan semakin baik pula. Hasil ini serupa dengan penelitian yang dilakukan oleh Mardijono (2008) bahwa partisipasi sangat ditentukan oleh persepsi tentang suatu objek. Ayunita dan Hapsari (2012) juga pernah melakukan penelitian tentang analisis persepsi dan partisipasi masyarakat pesisir pada KKLD Ujungnegoro, Kabupaten Batang. Hasil yang diperoleh dalam penelitian tersebut adalah terdapat hubungan antara persepsi masyarakat dengan tingkat partisipasi dalam pengelolaan KKLD.

Hasil uji koefisien determinasi adalah sebesar 33,9\%. Hal ini berarti kontribusi sebanyak 33,9\% partisipasi masyarakat pesisir terhadap pengelolaan KKLD Lampung Barat dipengaruhi oleh persepsi masyarakat pesisir tentang KKLD, sedangkan $66,1 \%$ sisanya disebabkan oleh faktor-faktor lain. Suroso et al. (2014) memaparkan bahwa ada beberapa faktor yang mempengaruhi partisipasi masyarakat dalam pembangunan dan pengelolaan yaitu tingkat pendidikan, usia, tingkat komunikasi, jenis pekerjaan dan tingkat kepemimpinan masyarakat. Pernyataan dari Suroso et al. (2014) juga menguatkan faktor-faktor yang mempengaruhi partisipasi masyarakat yang dipaparkan oleh Saptorini (2003). Lebih lanjut Saptorini (2003) mengungkapkan ada faktor lain yang mempengaruhi partisipasi masyarakat selain persepsi, yaitu adalah keadaan sosial masyarakat yang meliputi pendidikan, pendapatan, kebiasaan dan kedudukan dalam strata sosial. Tokoh masyarakat, tokoh agama, pemimpin adat juga berpengaruh dalam menggerakkan masyarakat sekitar untuk berpartisipasi dalam suatu kegiatan. 


\section{KESIMPULAN DAN SARAN}

Terdapat hubungan positif antara persepsi masyarakat pesisir tentang Kawasan Konservasi Laut Daerah (KKLD) dengan partisipasi masyarakat pesisir terhadap pengelolaan KKLD Lampung Barat. Hubungan antara kedua variabel tersebut memiliki nilai koefisien korelasi dengan kategori sedang. Berdasarkan hasil penelitian ini, perlu diadakannya penyuluhan atau sosialisasi lebih lanjut kepada masyarakat pesisir di Desa Muara Tembulih, Sukanegara dan Gedung Cahya Kuningan agar meningkatkan persepsi tentang KKLD, sehingga dapat meningkatkan partisipasi masyarakat terhadap pengelolaan KKLD Lampung Barat. Manfaatnya, kelestarian dan keberlanjutan sumber daya laut dan pesisir yang ada di KKLD Lampung Barat dapat terjaga dengan baik.

\section{UCAPAN TERIMAKASIH}

Peneliti memberikan rasa hormat dan terima kasihnya kepada Kepala Desa Sukanegara, Gedung Cahya Kuningan dan Muara Tembulih, serta kepada semua responden yang telah bekerja sama dengan peneliti.

\section{DAFTAR PUSTAKA}

Adhian, Suprapto D dan Purwanti F. 2014. Persepsi dan partisipasi nelayan dalam pengelolaan kawasan laut daerah Ujungnegoro-Roban Kabupaten Batang. Management of Aquatic Resources 3(3):28-33.

Arikunto S. 2008. Prosedur penelitian suatu pendekatan praktik. Rineka Cipta. Jakarta.

Ayunita DNND dan Hapsari TD. 2012. Analisis persepsi dan partisipasi masyarakat pesisir pada pengelolaan KKLD Ujungnegoro, Kabupaten Batang. SEPA 9(1):117-124.

Baba S, Isbandi, Mardikanto T dan Waridin. 2011. Pengaruh persepsi dan tingkat partisipasi dalam penyuluhan terhadap kinerja usaha peternak sapi perah di Kabupaten Enrekang. [Prosiding] Prosiding Seminar Nasional Teknologi Peternakan dan Veteriner 208-216.

[BPS] Badan Pusat Statistik Kabupaten Lampung Barat. 2018. Kabupaten Pesisir Barat dalam angka 2018. BPS Kabupaten Lampung Barat. Lampung Barat.

[Diskominfo] Dinas Komunikasi dan Informatika Kabupaten Pesisir Barat. 2020. Profil Kabupaten Pesisir Barat [internet]. Tersedia di: https://pesisirbarat kab.go.id/profil.

Haryanto AKP dan Sriyono. 2015. Hubungan tingkat pendidikan terhadap partisipasi petani dalam sapta usaha tani di desa Kebonharjo, Kecamatan Patebon, Kabupaten Kendal Tahun 2014. Edu Geography 3(3):7-14. 
KepDirJen KP3K (Keputusan Direktur Jenderal Kelautan, Pesisir dan Pulau-Pulau Kecil) Nomor Kep. 44/KP3K/2012 tentang pedoman teknis evaluasi efektivitas pengelolaan kawasan konservasi perairan, pesisir dan pulaupulau kecil.

Mamuko F, Walangitan H dan Tilaar W. 2016. Persepsi dan partisipasi masyarakat dalam upaya rehabilitasi hutan dan lahan di Kabupaten Bolaang Mongondow Timur. Eugenia 22(2):80-91.

Mardijono. 2008. Persepsi dan partisipasi nelayan terhadap pengelolaan kawasan konservasi laut Kota Batam [Tesis]. Program Studi Magister Manajemen Sumberdaya Pantai, Program Pascasarjana, Universitas Diponegoro. Semarang.

Monica YF dan Fauziah L. 2017. Partisipasi perempuan dalam pembangunan desa di Kecamatan Candi. Jurnal Kebijakan dan Manajemen Publik 5(2):217-228.

Mubarak Z. 2010. Evaluasi pemberdayaan masyarakat ditinjau dari proses pengembangan kapasitas pada kegiatan PNPM mandiri perkotaan di Desa Sastrodirjan, Kabupaten Pekalongan [Tesis]. Program Studi Magister Teknik Pembangunan Wilayah dan Kota, Program Pascasarjana, Universitas Dipenogoro. Semarang.

Muchlas M. 2005. Perilaku organisasi. Gadjah Mada University Press. Yogyakarta.

Nur F, Bulkis S dan Naping H. 2011. Partisipasi masyarakat dalam proses pembangunan infrastruktur desa, studi kasus: program alokasi dana desa di Desa Bialo, Kabupaten Bulukumba. Jurnal Pasca UNHAS 1-8.

Nurhidayat. 2012. Persepsi siswa SMP Putra Bangsa terhadap perilaku merokok di Kelurahan Kemiri Muka, Depok [Skripsi]. Program Studi Ilmu Keperawatan, Fakultas Ilmu Keperawatan, Universitas Indonesia. Depok.

Saptorini. 2003. Persepsi dan partisipasi masyarakat dalam pelaksanaan konservasi hutan mangrove di Kecamatan Sayung, Kabupaten Demak [Tesis]. Program Studi Magister Manajemen Sumberdaya Pantai, Program Pascasarjana, Universitas Diponegoro. Semarang.

Suroso H, Hakim A dan Noor I. 2014. Faktor-faktor yang mempengaruhi partisipasi masyarakat dalam perencanaan pembangunan di Desa Banjaran, Kecamatan Driyorejo, Kabupaten Gresik. Wacana 17 (1):7-15.

Sutami. 2009. Partisipasi masyarakat pada pembangunan prasarana lingkungan melalui program pemberdayaan masyarakat kelurahan (PPMK) di Kelurahan Marunda, Jakarta Utara [Tesis]. Program Studi Magister Teknik Pembangunan Wilayah dan Kota, Program Pascasarjana, Universitas Diponegoro. Semarang.

UU (Undang-Undang) Nomor 22 Tahun 2012 tentang pembentukan Kabupaten Pesisir Barat di Provinsi Lampung. 